\title{
Court blocks move of Arizona telescope
}

Washington. A US appeals court has backed the ruling of a district court in Tucson, Arizona, that the Forest Service exceeded its authority when it decided a new telescope at the Mount Graham International Observatory should be built 1,300 feet from its originally proposed location.

The 2:1 decision by the US ninth circuit court of appeals has upset officials at the University of Arizona, who point out that the proposed move was intended to assuage criticism that original building plans for the Large Binocular Telescope would disturb the habitat of the indigenous Mount Graham Red Squirrel. The move was made only

\section{Questionnaire row returns to the courts}

Tokyo. A nine-year dispute between faculty members of Hong Kong University over the legal rights to the contents of an epidemiological questionnaire is about to re-enter the colony's courts. On 18 April, the Hong Kong High Court ordered a judicial review of a recent internal inquiry by the university that cleared T. H. Lam, of the university's community medicine department, of charges of plagiarism (see Nature 373, 465; 1995).

The review was requested by Linda Koo of the same department and John Ho Hung Chiu, a professor in the department of radiation oncology. In 1992, Koo and Ho won a court case in which Lam had been charged with copying without their permission parts of a questionnaire that they had used for a cancer survey in the early 1980 s.

The verdict was upheld by the Court of Appeal the following year. But in January this year the university rejected the court Koo: expects a court rejected the court hearing soon decision. After its

own internal inquiry of Koo and Ho's claims against Lam, it cleared Lam of all charges of misconduct.

The High Court will now judge whether the university acted fairly in its internal inquiry. Koo and Ho claim that the inquiry was one-sided, as they were excluded from the hearings, and want the court to quash the university's report and prevent its further publication.

A university spokesman said on Monday that the university is unable to comment on the judicial review of its inquiry because the matter is sub judice. Koo says she expects a court hearing within the next few months.

David Swinbanks at the request of the biologists who had been monitoring the squirrels.

Construction work on the $\$ 60$-million telescope has been in abeyance since May 1994, when a petition to halt the work was filed by a coalition of local and national environmental groups concerned that the observatory not only threatened the future of the squirrel subspecies, but also offended local Apache tribes who consider the mountain to be sacred.

The petition charged that the move which the Forest Service claimed would reduce the impact of the observatory on the squirrels - violated the terms of the Arizona - Idaho Conservation Act, which sets out the conditions under which the observatory could be built.

In July last year, a district court judge supported the petition, ruling against the Forest Service (see Nature 370, 407; 1994). The service subsequently appealed against the decision to the circuit court of appeals. But last week, the latter court upheld the original ruling.

The main basis of the ruling given by the two judges who issued the majority opinion, was a sketch of proposed locations for the first three telescopes - out of a total of seven ultimately envisaged - contained in a 'biological opinion' submitted in 1988 by the Fish and Wildlife Service.

The judges agreed with the petitioners that the conservation act intended the telescopes to be placed in the locations in that sketch, and that the Forest Service did not have the authority to circumvent Congress by moving a telescope, even if it would benefit the squirrels.

But in a strongly-worded dissenting opinion, the third judge, Judge Cynthia Holcomb
Hall, disagreed. She claimed that minor adjustments in the locations of the telescopes could be requested by the Forest Service, which is responsible for ensuring that the impact of the observatory on the squirrels is minimized.

Hall pointed out that the majority opinion concedes that three structures have already been moved for this reason - one by 750 feet. There were no objections from environmental groups to the previous moves, and Hall claimed that moving the new telescope would be consistent with these precedents.

Peter Strittmatter, director of Steward Observatory, the leading partner in the development of the Mount Graham International Observatory, admits that the decision has set back the schedule for construction of the telescope.

But he adds that plans are now being drawn up to place the telescope in the location originally proposed in the 1988 biological opinion. Meanwhile, Strittmatter says he expects the University of Arizona to request a reconsideration of the decision.

Environmentalists' groups, which had challenged the decision to move the telescope on the grounds that it broke the agreement in Congress - and have already objected to trees on the mountain being removed by the university in preparation have welcomed last week's ruling.

But Strittmatter continues to argue that locating the observatory at the original site would have very little impact on the squirrels, and says that the new site would have even less. He points out that the total area devoted to the telescopes is only 8.6 acres out of a total squirrel habitat or more than 10,000 acres.

Leslie Sage

\section{Chiron expands gene therapy efforts}

San Francisco. Chiron Corporation, based in Emeryville, California, and one of the fastest growing US biotechnology companies, geared up last week to become a major player in gene therapy with the $\$ 95$-million purchase of Viagene Inc. of San Diego, California.

Calling gene therapy a very promising technology for drug development, Chiron officials said they had been attracted by Viagene's viral and nonviral gene transfer technology, its \$6-million manufacturing facility and its clinical experience.

"We believe that gene therapy is an important enabling technology that will yield innovative health care products across a broad spectrum of indications," said William J. Rutter, chairman of Chiron.

Chiron already has links with Progenitor Inc. of Columbus, Ohio, which specializes in nonviral vectors, and Ribozyme Pharmaceu- ticals Inc. of Boulder, Colorado, which has developed gene expression technology. Chiron and Viagene have collaborated since 1983, when Chiron purchased 17 per cent of the smaller company for about $\$ 20$ million.

Viagene has launched eight phase-I human clinical trials, and late last year began phase-II HIV trials with 190 patients. The company has focused on several types of cancer, HIV, haemophilia and hepatitis B. A joint trial with Chiron is currently testing gene therapy using interferon- $\gamma$ in tandem with interleukin- 2 for advanced metastatic melanoma.

According to Marc Schneebaum, senior vice president and chief financial officer of Genetic Therapy Inc., one of Viagene's leading competitors, Chiron's move illustrates the growing interest in gene therapy technology by large biotechnology and pharmaceutical companies. Sally Lehrman 